\title{
Biochemical adaptations of Nereis diversicolor (Polychaeta) to temporarily increased hydrogen peroxide levels in intertidal sandflats
}

\author{
Doris Abele-Oeschger, Rolf Oeschger, Hans Theede \\ Universität Bremen, Meereszoologie, Fachbereich 2, Außenstelle, Bürgermeister-Smidt-Str. 20, D-27568 Bremerhaven, \\ Germany
}

\begin{abstract}
Toxic hydrogen peroxide $\left(\mathrm{H}_{2} \mathrm{O}_{2}\right)$ is photochemically generated in hyperoxic and normoxic intertidal pools. Surprisingly high amounts of $\mathrm{H}_{2} \mathrm{O}_{2}$ penetrate the redoxcline, and are measurable in pore water in spite of the anoxic conditions prevailing there. Bioturbate macrofauna inhabiting these sediments encounters oxic conditions with peroxide in surface pools and anoxic conditions with peroxide in the sediment. We studied antioxidative properties in the polychaete Nereis diversicolor. Antioxidant enzyme activities of catalase and superoxide dismutase (SOD) showed annual variations correlated to the environmental peroxide concentrations. Epitokous specimens from April exhibited very high enzyme activities. Catalase was predominantly localised in the mitochondria and is inducible by peroxide incubation under experimental conditions. SOD activities were not inducible during oxic peroxide incubation. In contrast, SOD had higher activities when the worms were kept anoxically in the presence of hydrogen sulfide $(100 \mu \mathrm{M})$ or hydrogen peroxide $(5 \mu \mathrm{M})$. The radical stress the worms encountered during anoxic peroxide incubation was reflected by a highly increased lactate formation. Under oxic conditions $500 \mathrm{nM} \mathrm{H} \mathrm{H}_{2} \mathrm{O}_{2}$ decreased oxygen uptake of $N$. diversicolor by $38 \%$. In epitokous $N$. diversicolor, this was accompanied by a conversion of heme to the green pigment biliverdin, a potent antioxidant. Biliverdin was accumulated by the worms during oogenesis under natural conditions. Therefore its formation during spawning seems to be a response to increasing hydrogen peroxide concentrations in sediment pore water during spring. Biliverdin was not formed under anoxic conditions, because the conversion requires oxygen. Atokous worms lacked the ability to form biliverdin when exposed to peroxide.
\end{abstract}

KEY WORDS: Nereis diversicolor $\cdot$ Antioxidant protection $\cdot$ Biliverdin

\section{INTRODUCTION}

During the past few years, formation of $\mathrm{H}_{2} \mathrm{O}_{2}$ in marine and fresh water environments has been measured by only few authors (Zika et al. 1985, Szymczak \& Waite 1988, Moffett \& Zafiriou 1990). A methodological survey of the applied assays was made by Price et al. (1992). $\mathrm{H}_{2} \mathrm{O}_{2}$ formation is gaining more attention since the decomposition of ozone in the atmosphere and the deleterious effects of increasing UV irradiation on living organisms have been recognized. $\mathrm{H}_{2} \mathrm{O}_{2}$ is the first stable reaction product of photodynamic (UV driven) oxygen reduction in aqueous media:

$$
\mathrm{O}_{2} \stackrel{\downarrow \mathrm{UV}}{\longrightarrow} \mathrm{O}_{2}^{--}
$$

$$
2 \mathrm{H}_{2} \mathrm{O}+\mathrm{O}_{2}{ }^{--} \longrightarrow 2 \mathrm{H}_{2} \mathrm{O}_{2} \text { (hydrogen peroxide) }
$$

$\mathrm{H}_{2} \mathrm{O}_{2}$ is an uncharged nonradical active oxygen species. It diffuses through cell membranes and inside the cells liberates other reactive oxygen species, mainly -OH radicals. These radicals initiate radical chain reactions leading to formation of lipid peroxides, affecting the membrane lipids, membrane-bound enzymes and other macromolecules. Eventually this leads to membrane leakage, breakdown of the cellular metabolism, and finally tissue damage.

All organisms including marine invertebrates have developed effective radical protection. Oxygen radicals $\left(\mathrm{O}_{2}{ }^{-}\right)$generated in peroxisomes and mitochondria are converted to hydrogen peroxide by the enzyme 
superoxide dismutase (SOD: $\mathrm{O}_{2}{ }^{-}+2 \mathrm{H}_{2} \mathrm{O} \rightarrow 2 \mathrm{H}_{2} \mathrm{O}_{2}$ ). Hydrogen peroxide is metabolized to oxygen and water by catalase or glutathione peroxidase (GP). Catalase protects the cells from externally generated as well as internally formed peroxide.

Besides photochemical generation, $\mathrm{H}_{2} \mathrm{O}_{2}$ has biological as well as microbiological sources in the marine environment (Palenik \& Morel 1988, Elstner 1990). Especially in intertidal environments, $\mathrm{H}_{2} \mathrm{O}_{2}$ formation occurs in shallow surface pools, where photosynthetic oxygen production by benthic algae leads to frequent oxygen supersaturation. Moreover hydrogen peroxide occurs in elevated concentrations in sediment pore water of intertidal sandflats. Although Bittersohl (1971) found that autoxidation of sulfide can lead to $\mathrm{H}_{2} \mathrm{O}_{2}$ formation, the chemical or microbial reactions leading to peroxide generation in anoxic sediment pore water are still unclear. Previous measurements (Abele-Oeschger \& Oeschger unpubl.), however, showed that animals in intertidal sediments not only encounter oxic conditions with peroxide in tide pools, but also anoxic conditions with peroxide in sediment pore water. Most macrofauna organisms try to avoid the second situation by irrigating their burrows with oxic surface water.

It is the objective of this paper to study the physiological reactions and enzymatic as well as other biochemical adaptations of the polychaete Nereis diversicolor to environmental $\mathrm{H}_{2} \mathrm{O}_{2}$ under oxic and anoxic conditions. Additionally, generation of oxygen radicals in the polychaetes during anoxic $\mathrm{H}_{2} \mathrm{~S}$ incubation was studied by determining the resulting increase in antioxidant enzyme activity levels in the tissue.

\section{MATERIAL AND METHODS}

Study site. Nereis diversicolor specimens were collected from a sandy intertidal area on the North Sea coast at Dorum, near Bremerhaven, Germany. Salinity here ranges between 22 and $28 \%$. The macrofauna at this location is dominated by the polychaetes Arenicola marina, Heteromastus filiformis, and $N$. diversicolor. These polychaetes are bioturbators, which enhance penetration of oxic, peroxide-containing surface water into deeper anoxic sediment layers through burrow constructions and feeding movements.

Enzymatic assays. Catalase: Catalase activity (EC 1.11.1.6) was determined after Aebi (1985). Samples were homogenised in $50 \mathrm{mM}$ potassium phosphate buffer. Homogenates were assayed in potassium phosphate buffer ( $50 \mathrm{mM}, \mathrm{pH} 7.0$ ) containing $\mathrm{H}_{2} \mathrm{O}_{2}$ as substrate in a spectrophotometer at $240 \mathrm{~nm}$.

Superoxide dismutase (SOD): SOD (EC 1.15.1.1) activity was determined after Marklund \& Marklund (1974). The assay is based on the ability of SOD to in- hibit the autoxidation of pyrogallol in a $0.05 \mathrm{M}$ Trissuccinate buffer $(\mathrm{pH}$ 8.2). The buffer was aerated for $1 \mathrm{~h}$ prior to use. Addition of $50 \mu \mathrm{l}$ pyrogallol solution $\left(0.57 \mathrm{mg} \mathrm{ml} \mathrm{m}^{-1}\right)$ to $950 \mathrm{\mu l}$ buffer resulted in an absorbance increase of $0.020 \mathrm{abs} \mathrm{min}^{-1}$ at $420 \mathrm{~nm}$. Inhibition of this increase by $50 \%\left(=0.010 \mathrm{abs} \mathrm{min}^{-1}\right)$ was defined as $1 \mathrm{U}$ of SOD activity. Inhibition was tested using a SOD standard from bovine erythrocytes (Boehringer, Mannheim, Germany).

Glutathione reductase (GR): The applied GR (EC 1.6.4.2.) assay is based on the reaction GSSG + $\mathrm{NADPH}+\mathrm{H}^{+} \leftrightarrow 2 \mathrm{GSH}+\mathrm{NADP}^{+}$. The oxidation of NADPH is measured as decrease of absorbance at $340 \mathrm{~nm}$. Deep-frozen tissue samples were grounded in liquid nitrogen and extracted with $0.12 \mathrm{M}$ phosphate buffer ( $\mathrm{pH} 7.2$ ) using a 1:3 (w:v tissue:buffer) relation. Glutathione reductase activity was assayed photometrically at $340 \mathrm{~nm}$ and $25^{\circ} \mathrm{C}$ using $1250 \mu \mathrm{l}$ Tris buffer (100 mM, pH 8.0), to which $50 \mu$ EDTA $(0.94 \mathrm{mM})$, $100 \mu \mathrm{lSSSG}(4.6 \mathrm{mM})$ and $25 \mu \mathrm{l}$ NADPH $(0.16 \mathrm{mM})$ were added. After mixing, the assay was started with $25 \mu \mathrm{l}$ homogenate. A GR standard was purchased from Boehringer (120 $\mathrm{U} \mathrm{mg}^{-1}$ ) and diluted in Tris buffer.

Glutamate dehydrogenase: The mitochondrial marker enzyme glutamate dehydrogenase $(G D H$, reverse, aminating, EC 1.4.1.3.) was determined in homogenates of whole worms and different cell fractions after homogenisation in $1: 5(\mathrm{w}: \mathrm{v})$ of ice-cold $50 \mathrm{mM}$ potassium phosphate buffer $(\mathrm{pH} 7.6$, with $1 \mathrm{mM}$ EDTA and $14 \mathrm{mM}$ mercaptoethanol). The different fractions were passed through Sephadex G-25 columns after centrifugation. Assay buffer consisted of 50 mM TRA, pH 7.6, containing $20 \mathrm{mM} 2$-oxoglutarate, $100 \mathrm{mM}$ ammonium acetate, $0.15 \mathrm{mM} \mathrm{NADH}, 1 \mathrm{mM}$ ADP and 2 mM EDTA.

Cell fractionation: Eight polychaetes (1 to $1.6 \mathrm{~g}$ fresh mass) were pooled, omitting head (prostomium and metastomium) and tail-end (pygidium) parts. The specimens were homogenised in $20 \mathrm{mM}$ Tris- $\mathrm{HCl}$ buffer ( $\mathrm{pH}$ 7.6). Cell compartments were fractionated by differential ultracentrifugation according to Livingstone et al. (1992). Catalase activity was assayed in Tris buffer. SOD activities were partly inhibited due to an inappropriate ionic strength of the homogenisation buffer. Thus for SOD assays, pelleted mitochondria and microsomes were redissolved in Tris-succinate buffer (see above). Only the cytosolic activity was determined in Tris- $\mathrm{HCl}$ homogenisation buffer, causing an underestimation of the real activities in this fraction.

Determination of metabolites. After extraction with $0.6 \mathrm{~N} \mathrm{HClO}_{4}$, the metabolite succinate was measured using the standard enzymatic determination (Beutler 1985).

D-lactate in same extracts was measured after Noll (1974). We used D-lactate as an indicator for enhanced 
glycolytic activity, since lactate dehydrogenase is the only pyruvate oxidoreductase found in nereid polychaetes (Livingstone et al. 1983, 1990).

Oxygen consumption measurements. Oxygen uptake $\left(\mathrm{MO}_{2}\right)$ was measured in a flow respirometer (as described previously) in chambers of $4 \mathrm{ml}$ volume and perfused at a flow rate of 35 to $40 \mathrm{ml} \mathrm{h}^{-1}$ of filtered seawater $(0.45 \mu \mathrm{m}$, salinity $22 \%)$ at $10 \pm 0.1^{\circ} \mathrm{C}$ (Oeschger et al. 1992). Continuously recorded $\mathrm{MO}_{2}$ (up to $21 \mathrm{~h}$ on individual worms) was calculated by integrating recorded area of the charts with a VIDS III digitalizing program. Values were calculated on an averaged hourly basis. The normoxic oxygen consumption of each individual worm was measured before and after exposing them to 0.5 and $5 \mu \mathrm{M} \mathrm{H}_{2} \mathrm{O}_{2}$ for $6 \mathrm{~h}$ in $500 \mathrm{ml}$ aerated seawater without sediment. $\mathrm{H}_{2} \mathrm{O}_{2}$ concentrations were monitored during exposure and re-adjusted to experimental levels when necessary. The first 2 to $3 \mathrm{~h}$ of oxygen consumption were omitted to avoid handling stress after insertion into the respiration chamber. After each measurement, oxygen consumption of empty chambers was monitored and subtracted from measurements on Nereis diversicolor. Additionally, control measurements of worms kept oxic for some days without treatment were also performed, to test a possible influence of the duration time of keeping them in aquaria. Dry weight of whole worms (33.6 to $99.4 \mathrm{mg}$ ) was determined after $2 \mathrm{~d}$ of drying at $108^{\circ} \mathrm{C}$.

Pigment analysis. Pigments were extracted from deep-frozen animal tissue with ethanol or ether. Analysis was carried out with a Kontron HPLC system on an RP-C18 silica gel column. The binary solvent system consisted of methanol/water (A: 80:20) and methanol/acetone (80:20). Carotenoids were detected with a flow-through photometer at $440 \mathrm{~nm}$. For identification and calibration a $\beta$-carotene standard (Fluka) was used.

Biliverdin. Biliverdin was measured in whole worms using the method of Makos \& Youson (1988). For each measurement 200 to $400 \mathrm{mg}$ of deep-frozen tissue was used. Contents were measured photometrically at $535 \mathrm{~nm}$ and calibrated with a biliverdin standard (Sigma).

\section{RESULTS}

\section{Annual variations of oxygen-radical and peroxide- metabolizing enzymes}

Catalase and SOD in freshly captured Nereis diversicolor were measured between February 1992 and February 1993 (Fig. 1). At each sampling occasion 8 to 12 individuals were analysed. Low activity levels of both

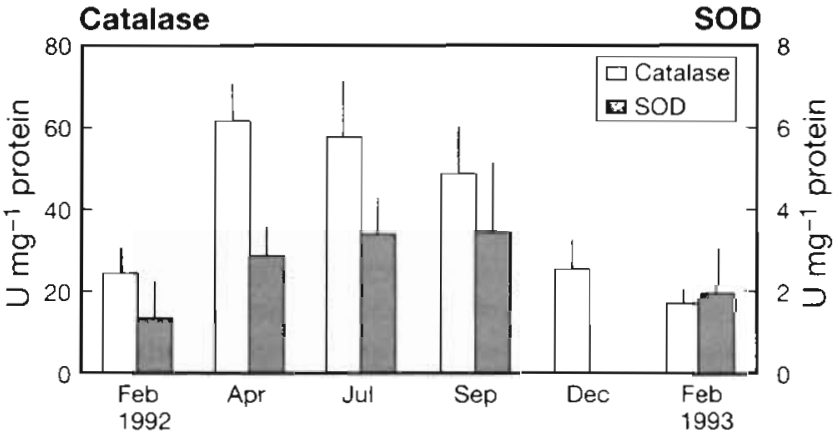

Fig. 1. Nereis diversicolor. Activities (means $\pm \mathrm{SD}$ ) of antioxidant enzymes catalase and SOD in freshly captured specimens from the Wadden intertidal (Dorum, Germany) between February 1992 and February 1993

enzymes were measured during the winter months, while increased activities were found between April and September 1992.

\section{Catalase and SOD activities in different cell compartments}

Catalase activities were measured in different cell compartments (mitochondrial, microsomal fraction, and the cytosolic fraction) after differential centrifugation. This experiment was conducted in April 1993 with epitokous worms (Table 1), and repeated in September 1993 with atokous worms. During the second experiment additional measurements of SOD activities in the cell compartments were performed (Table 1). Glutamate dehydrogenase $(\mathrm{GDH})$ was measured as the mitochondrial marker enzyme.

Table 1. Nereis diversicolor. Specific activities ( $\mathrm{U} \mathrm{mg}^{-1}$ protein) of the enzymes catalase, SOD (epitokous worms only) and glutamate dehydrogenase in different cell compartments of pooled whole specimens. Data represent the arithmetic means of duplicate preparations from April 1993 (epitokous) to September 1993 (atokous). -: not determined

\begin{tabular}{|lccc|}
\hline & Catalase & SOD & GDH \\
\hline Epitokous & & & \\
Whole worm & 33.79 & 4.395 & 0.029 \\
Mitochondrial fraction & 80.4 & 2.355 & 0.171 \\
Microsomal fraction & 19.75 & 3.405 & 0.018 \\
Cytosolic fraction & 23.04 & 8.78 & 0.041 \\
& & & \\
Atokous & & & \\
Whole worm & 28.3 & - & 0.011 \\
Mitochondrial fraction & 199.1 & - & 0.22 \\
Microsomal fraction & 7.6 & - & 0.002 \\
Cytosolic fraction & 5.5 & - & 0.006 \\
\hline
\end{tabular}


Highest catalase activities correlated with high activity of GDH in the mitochondrial fraction of epitokous and atokous worms. Much lower catalase activity was found in the microsomal and the cytosolic fraction. SOD activity in atokous individuals was not so clearly related to a cell compartment. The cytosolic fraction had the greatest specific activity, while the activity in the mitochondrial and microsomal fraction was comparably lower. In fact the lowest activities per mg protein of this enzyme were measured in the mitochondrial fraction.

\section{Physiological reactions of Nereis diversicolor to environmental $\mathrm{H}_{2} \mathrm{O}_{2}$}

Oxygen uptake under peroxide incubation

Under oxic conditions peroxide reduced oxygen uptake by the worms by $38.0 \pm 7.7 \%\left(0.5 \mu \mathrm{M} \mathrm{H}_{2} \mathrm{O}_{2}, \mathrm{n}=3\right)$ and $39.4 \pm 9.8 \%\left(5 \mu \mathrm{M} \mathrm{H}_{2} \mathrm{O}_{2}, \mathrm{n}=5\right)$. The difference of the applied concentrations did not produce a linear dose response relationship with respect to oxygen consumption, i.e. the higher peroxide concentration $(5 \mu \mathrm{M})$ did not lead to a more pronounced decline of the respiration rate than the lower concentration (Table 2). Fig. 2 depicts the changes in oxygen consumption of a worm

Table 2. Nereis diversicolor. Oxygen consumption before and after oxic exposure to 0.5 and $5 \mu \mathrm{M} \mathrm{H}_{2} \mathrm{O}_{2}$ for $6 \mathrm{~h}$ at $10^{\circ} \mathrm{C}$ and $22 \%$ S without sediment. Worms without $\mathrm{H}_{2} \mathrm{O}_{2}$ treatment were measured to rule out an influence due to keeping them in aquaria. Data are given as means of averaged hourly oxygen consumption. Numbers in parenthesis: total measuring time (h)

\begin{tabular}{|c|c|c|}
\hline \multicolumn{2}{|c|}{$\begin{array}{l}\text { Oxygen consumption } \\
\left(\mu \mathrm{mol} \mathrm{h} \mathrm{h}^{-1} \mathrm{~g}^{-1} \text { dry mass }\right)\end{array}$} & \multirow[t]{2}{*}{$\%$ Reduction } \\
\hline Before treatment & After treatment & \\
\hline \multicolumn{3}{|l|}{ No exposure to $\mathrm{H}_{2} \mathrm{O}_{2}$} \\
\hline $12.77(17)$ & $13.10(14)$ & - \\
\hline $12.22(11)$ & $13.48(13)$ & - \\
\hline $10.20(21)$ & $9.70(12)$ & - \\
\hline \multicolumn{3}{|c|}{ Exposure to $0.5 \mu \mathrm{M} \mathrm{H}_{2} \mathrm{O}_{2}$} \\
\hline $20.79(13)$ & $11.50(15)$ & 44.7 \\
\hline $23.30(12)$ & $14.06(10)$ & 39.7 \\
\hline $21.79(15)$ & $15.34(16)$ & 29.4 \\
\hline & \multicolumn{2}{|c|}{ Mean reduction: $38.0 \pm 7.7$} \\
\hline \multicolumn{3}{|c|}{ Exposure to $5 \mu \mathrm{M} \mathrm{H} \mathrm{H}_{2} \mathrm{O}_{2}$} \\
\hline $34.56(13)$ & $19.47(17)$ & 43.8 \\
\hline $24.30(18)$ & $17.20(16)$ & 29.3 \\
\hline $21.50(10)$ & $12.18(14)$ & 43.4 \\
\hline $26.25(12)$ & $18.62(14)$ & 29.1 \\
\hline $14.63(13)$ & $7.14(16)$ & 51.2 \\
\hline \multicolumn{3}{|c|}{ Mean reduction: $39.4 \pm 9.8$} \\
\hline
\end{tabular}

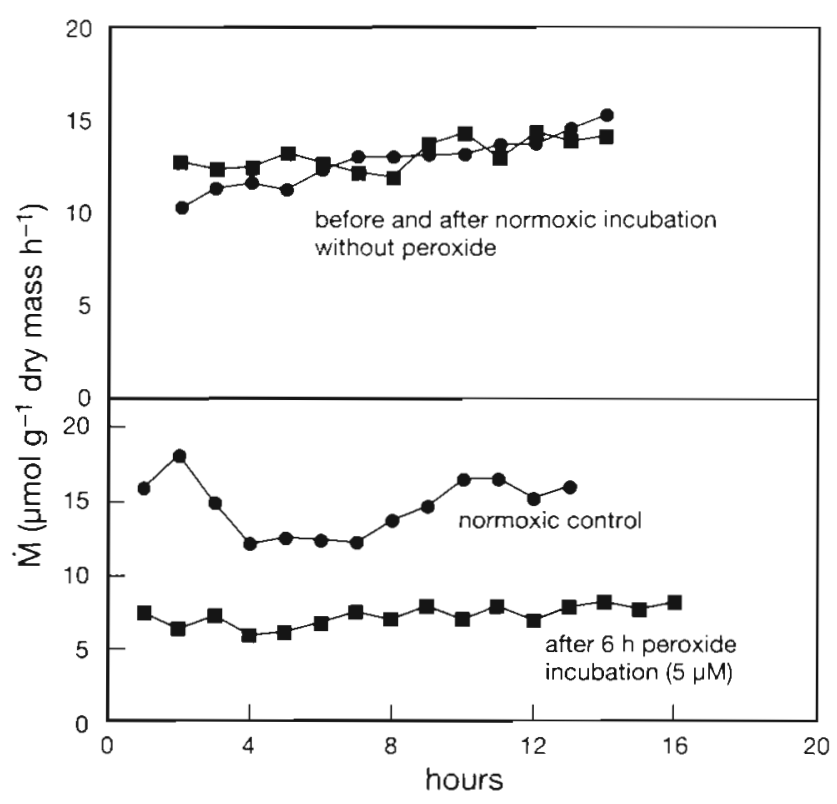

Fig. 2. Nereis diversicolor. Oxygen consumption of an individual worm before ( ) and after ( $\square$ ) 6 h normoxic incubation

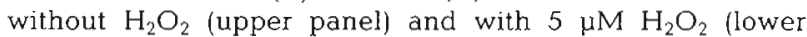
panel). Oxygen consumption averaged on an hourly basis

before and after incubation and a worm without treatment kept under the same conditions without added $\mathrm{H}_{2} \mathrm{O}_{2}$. This was a control to rule out possible influence due to keeping the worms in aquaria. During incubation, worms stopped moving around in the incubation flask and instead curled up at the bottom. After incubation some worms were transferred to normoxic seawater and sediment without $\mathrm{H}_{2} \mathrm{O}_{2}$. These worms recovered and showed no visible alterations in their behaviour 2 and $3 \mathrm{~d}$ after this transfer.

\section{Metabolites}

Accumulation of the anaerobic metabolites succinate and lactate was measured in Nereis diversicolor specimens after $6 \mathrm{~h}$ oxic and anoxic incubations with and without $4 \mu \mathrm{M}$ peroxide. Data are summarized in Fig. 3. Under oxic conditions addition of peroxide to the incubation water did not yield an increase in succinate or lactate levels. In contrast anoxic incubation without peroxide led to a significant increase of the succinate and the lactate concentrations. Slightly higher succinate levels accumulated when the animals were incubated under anoxic conditions with $4 \mu \mathrm{M}$ peroxide. However, lactate levels were significantly greater after anoxic $4 \mu \mathrm{M}$ peroxide treatment, the absolute concentration amounting to $55.7 \mu \mathrm{mol}$ $\mathrm{g}^{-1}$ dry mass, compared to $19.7 \mu \mathrm{mol} \mathrm{g}^{-1}$ dry mass in the anoxic control group. 


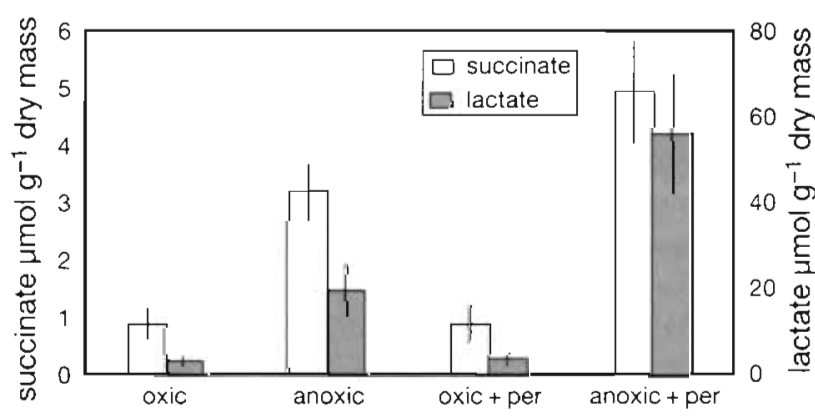

Fig. 3. Nereis diversicolor. Succinate and lactate accumulation (means \pm SD) in incubated worms. Each group comprises 7 to 10 individuals. Incubations were performed over $6 \mathrm{~h}$ under the conditions indicated in the text, 'per' $=4 \pm 0.5 \mu \mathrm{M}$ $\mathrm{H}_{2} \mathrm{O}_{2}$

\section{Biochemical adaptations of Nereis diversicolor to environmental $\mathrm{H}_{2} \mathrm{O}_{2}$}

Changes in antioxidant enzyme activities during oxic and anoxic peroxide incubation

Oxic incubations with peroxide were performed during summer (July-September 1992) to test the effect of elevated environmental peroxide concentrations on the activities of peroxide (catalase) and oxygen radical quenching enzymes (SOD). These experiments were limited to $2 \mathrm{~h}$, because the objective was to test shortterm adaptability to fluctuating peroxide concentrations at a time of the year, when the in situ peroxide levels reach the highest annual concentrations. Peroxide incubation experiments conducted between December 1992 and February 1993 did not yield significant responses of catalase activity. This was attributed to the reduced metabolic activity of the worms during winter and the data were not included.
The results from the summer peroxide incubations are summarized in Table 3. Catalase activity was induced by 3 and $10 \mu \mathrm{M} \mathrm{H}_{2} \mathrm{O}_{2}$ under oxic conditions. SOD activity was not inducible by $3 \mu \mathrm{M}$ peroxide, and the observed activity increase resulting from $10 \mu \mathrm{M}$ peroxide incubation was not significant. A significant increase of SOD activity was found only after anoxic $10 \mu \mathrm{M}$ peroxide incubation. The enzyme activity levels increased about 3-fold compared to freshly captured animals and to the anoxic control group $(\mathrm{p}<0.01)$.

Glutathione reductase activity in freshly captured specimens was about $0.015 \mathrm{U} \mathrm{mg}^{-1}$ protein throughout the year, and was not inducible during oxic hydrogen peroxide exposure.

\section{Biliverdin}

Elevated biliverdin tissue levels of freshly captured specimens were measured during the spawning period of Nereis diversicolor in April 1993. In fact tissue levels were twice as high compared to the atokous specimens collected in September 1993 (Table 4). Oxic $4 \mu \mathrm{M}$ peroxide incubation yielded a 2 -fold increase of the biliverdin tissue concentrations only in epitokous $N$. diversicolor specimens ( $\mathrm{p}<0.01)$. This was accompanied by a visible colour change from pale brown to green of the worms tissues. Microscopical observations revealed that mainly the dorsal and the dorsolateral blood vessels turned green during incubation. In atokous specimens biliverdin formation was not inducible upon oxic peroxide incubation.

\section{Carotenoids}

Tissue extracts of Nereis diversicolor contained a single carotenoid peak, which was identified as $\beta$-carotene in 2 different isomer forms. Besides $\beta$-carotene, no

Table 3. Nereis diversicolor. Specific activities (means $\pm \mathrm{SD}, \mathrm{n}=10, \mathrm{U} \mathrm{mg}^{-1}$ protein) of the enzymes catalase and SOD in freshly captured worms (July and August 1992) and in specimens after $2 \mathrm{~h}$ normoxic and anoxic $\mathrm{H}_{2} \mathrm{O}_{2}$ incubation compared to normoxic controls without peroxide. 'Significantly different from normoxic controls $(p<0.05)$

\begin{tabular}{|c|c|c|c|c|}
\hline \multirow[t]{2}{*}{$\mathrm{H}_{2} \mathrm{O}_{2}(\mu \mathrm{M})$} & \multirow[t]{2}{*}{ Condition } & \multicolumn{3}{|c|}{ Activity } \\
\hline & & Freshly captured & After $\mathrm{H}_{2} \mathrm{O}_{2}$ incubation & Normoxic controls \\
\hline \multicolumn{5}{|l|}{ Catalase } \\
\hline 1 & Normoxic & $57.3 \pm 14$ & $32.5 \pm 12.4$ & $40.8 \pm 9.8$ \\
\hline 3 & Normoxic & $61.3 \pm 9.8$ & $96.2 \pm 25.3^{\circ}$ & $66.7 \pm 24.8$ \\
\hline 10 & Normoxic & $48.2 \pm 125$ & $88.3 \pm 16.8^{\circ}$ & $37.5 \pm 10.5$ \\
\hline \multicolumn{5}{|l|}{ SOD } \\
\hline 3 & Normoxic & $2.83 \pm 0.7$ & $1.80 \pm 0.9$ & $1.24 \pm 0.23$ \\
\hline 10 & Normoxic & $3.41 \pm 1.71$ & $5.17 \pm 2.25$ & $2.39 \pm 2.8$ \\
\hline 10 & Anoxic & $2.61 \pm 0.82$ & $8.84 \pm 3.25^{\circ}$ & $2.0 \pm 1.7$ \\
\hline
\end{tabular}


Table 4. Nereis diversicolor. Biliverdin content $\left(\mathrm{\mu g} \mathrm{g}^{-1}\right.$ fresh mass) in freshly captured specimens from epitokous worms (April 1993) and atokous worms (September 1993) and after $6 \mathrm{~h}$ oxic incubation in $4 \pm 0.5 \mu \mathrm{M} \mathrm{H}_{2} \mathrm{O}_{2}$. "Significantly different from atokous worms $(\mathrm{p}<0.05)$

\begin{tabular}{|ccc|}
\hline & Freshly captured & $\begin{array}{c}\text { After } \mathrm{H}_{2} \mathrm{O}_{2} \\
\text { incubation }\end{array}$ \\
\hline Epitokous worms & $\begin{array}{c}91.2 \pm 31.6 \\
(\mathrm{n}=6)\end{array}$ & $\begin{array}{c}201.0 \pm 86.0^{\circ} \\
(\mathrm{n}=7)\end{array}$ \\
Atokous worms & $\begin{array}{c}43.7 \pm 11.01 \\
(\mathrm{n}=5)\end{array}$ & $\begin{array}{c}38.21 \pm 8.5 \\
(\mathrm{n}=7)\end{array}$ \\
\hline
\end{tabular}

other carotenoid occurred. A total of 5 individuals were analysed.

\section{Changes of antioxidant enzyme activities due to anoxia and sulfide}

Effects of anoxia and hydrogen sulfide on SOD and catalase were tested in epitokous and atokous individuals (Table 5). Anoxia for 6 h slightly increased SOD activities in epitokous worms, and decreased SOD activities in atokous specimens. Anoxic $100 \mu \mathrm{M}$ sulfide incubation significantly increased SOD activities in atokous worms $(p<0.01)$ compared to oxic and anoxically kept control groups. In epitokous specimens SOD activity was also higher after anoxic sulfide incubation although the effect was not significant.

Catalase activities were significantly higher in freshly captured epitokous worms $\left(63 \pm 11 \mathrm{U} \mathrm{mg}^{-1}\right.$ pro-

Table 5. Nereis diversicolor. Catalase and SOD activities (U $\mathrm{mg}^{-1}$ protein) in epitokous and atokous individual whole worms and of worms after $6 \mathrm{~h}$ anoxic incubation with and without $100 \mu \mathrm{M}$ sulfide. "Significantly different from normoxic controls $(p<0.05)$

\begin{tabular}{|c|c|c|}
\hline & Catalase & SOD \\
\hline \multicolumn{3}{|l|}{ Epitokous worms } \\
\hline Normoxic controls & $\begin{array}{c}63.03 \pm 11.3 \\
(n=8)\end{array}$ & $\begin{array}{c}1.74 \pm 0.9 \\
(n=5)\end{array}$ \\
\hline 6 h anoxia & $\begin{array}{c}77.10 \pm 20.9 \\
(\mathrm{n}=8)\end{array}$ & $\begin{array}{c}2.18 \pm 0.9 \\
(n=5)\end{array}$ \\
\hline $6 \mathrm{~h}$ anoxia + sulfide & $\begin{array}{c}67.55 \pm 11.6 \\
(n=9)\end{array}$ & $\begin{array}{c}2.50 \pm 1.1 \\
(n=9)\end{array}$ \\
\hline \multicolumn{3}{|l|}{ Atokous worms } \\
\hline Normoxic controls & $\begin{array}{c}32.58 \pm 11.6 \\
(\mathrm{n}=5)\end{array}$ & $\begin{aligned} & 2.38 \pm 0.65 \\
&(\mathrm{n}=5)\end{aligned}$ \\
\hline $6 \mathrm{~h}$ anoxia & $\begin{array}{c}42.23 \pm 14.9 \\
(\mathrm{n}=9)\end{array}$ & $\begin{array}{c}1.55 \pm 0.9 \\
(\mathrm{n}=8)\end{array}$ \\
\hline $6 \mathrm{~h}$ anoxia + sulfide & $\begin{array}{c}50.80 \pm 19.0^{\circ} \\
(\mathrm{n}=8)\end{array}$ & $\begin{array}{c}3.85 \pm 1.1 . \\
(n=10)\end{array}$ \\
\hline
\end{tabular}

tein), compared to atokous specimens $\left(33 \pm 12 \mathrm{U} \mathrm{mg}^{-1}\right.$ protein). In epitokous worms catalase activities were unaffected by anoxia and anoxic $100 \mu \mathrm{M}$ sulfide incubation. Atokous specimens had insignificantly greater activities after sulfide incubation.

\section{DISCUSSION}

The Wadden intertidal provides living conditions in which the transitional zone between hyperoxia, due to photosynthetic activity of benthic microalgae and hypoxia beneath the sediment surface, can be very small. Variations of hydrogen peroxide concentrations in intertidal pools from the sampling area reflect a clear-cut seasonality, with winter values below $500 \mathrm{nM}$ (October-March), while in summer (April-September) concentrations of $5000 \mathrm{nM}$ and more were reached (Abele-Oeschger \& Oeschger unpubl.). According to our knowledge our data set contains the only reports on hydrogen peroxide concentrations in pore water and tidal pools. Data available from open seawater range between 20 and $300 \mathrm{nM}$ (Zika et al. 1984, 1985, Szymczak \& Waite 1988, Pamatmat 1990, Price et al. 1992). And our measurements in subtidal pore water from the German Bight amounted to less than $300 \mathrm{nM}$ peroxide in June 1993 (Abele-Oeschger \& Oeschger unpubl.). The situation in intertidal areas is complicated by temporary appearance of sulfide in the sediment when oxygen supply is reduced (under algal mats), or when oxygen is completely consumed by chemical and microbial demineralisation of organic matter.

It is an open question how peroxide formation in the sediment surface, and moreover the interaction of peroxide and sulfide, affect benthic macrofauna organisms in intertidal sediments. Morrill et al. (1988) found that invertebrate macro- and meiofauna may have considerable activities of the peroxide-decomposing enzyme catalase and of the oxygen-radical quenching enzyme SOD. These authors also found that thiobiotic meiofauna has higher catalase levels than oxibiotic.

The polychaete Nereis diversicolor is a typical inhabitant of intertidal sandflats. The worms often inhabit deeper sediment strata, and pump a daily load of $10 \mathrm{l}$ oxygenated, $\mathrm{H}_{2} \mathrm{O}_{2}$-containing water per individual through their burrows (Riisgård 1991). During low tide periods, when the sediment surface is uncovered by water, $N$. diversicolor drags air bubbles into its burrows by vigorous body contractions. The bubbles are retained inside the burrow for some minutes and then exchanged for new bubbles. This kind of 'ebb-ventilation' was first described by Lindroth (1941). According to this author this is a common behavioural feature of several intertidal macrofauna organisms. Although $N$. 
diversicolor is an oxibiotic species, it is often encountered in sulfidic sediments and exhibits a considerable sulfide tolerance, mainly due to the ability to oxidise $\mathrm{H}_{2} \mathrm{~S}$ to thiosulfate. Under unfavourable environmental conditions, i.e. long-lasting anoxia or too high sulfide levels, $N$. diversicolor is able to switch to extended anaerobiosis (Schötler 1979, Jahn et al. 1992). Altogether this species seems to be an ideal object for multifactorial studies of hydrogen peroxide and sulfide effects

Although data on marine benthic species are scarce, the activity levels of oxygen radical and peroxide metabolizing enzymes in adult invertebrate organisms seem highly variable. Catalase activities in Nereis diversicolor compare well with the activities in subtidal macrofauna, measured by Morrill et al. (1988). In contrast, SOD activity levels in $N$. diversicolor range between 0.5 and $4 \mathrm{U} \mathrm{mg}^{-1}$ protein and are far lower, compared to those of Morrill and co-authors. This discrepancy may be due to different methods used for SOD and protein analyses. Generally SOD levels in $N$. diversicolor seem comparatively low, as we measured higher levels in Phyllodoce mucosa, another polychaete species from the same area (Abele-Oeschger \& Oeschger unpubl.). Catalase activity in $N$. diversicolor is predominantly localized in the mitochondrial fraction. The enzyme is easily inducible upon peroxide incubation, and it therefore seems convincing that the higher catalase activities in freshly captured worms during summer correlate to the summer maxima of environmental peroxide.

SOD activities are primarily concentrated in the cytosolic and the microsomal fraction. Although SOD activities followed the same seasonal pattern as catalase, i.e. high activities in summer, low in winter, SOD activity levels were not altered significantly during oxic peroxide incubation. This was attributed to the fact that SOD does not detoxify $\mathrm{H}_{2} \mathrm{O}_{2}$, and moreover showed that peroxide incubation does not lead to a significant production of $\mathrm{O}_{2}{ }^{--}$radicals in the worm's tissue. Moreover peroxide incubation did not lead to an increase of glutathione reductase (GR), another enzyme with an antioxidant function. So, beside catalase and $\beta$-carotene, which is known as a potent radical scavenger (Burton \& Ingold 1984, Zamora et al. 1991), the worms need further protection against environmental peroxide. At least during spring, when $\mathrm{H}_{2} \mathrm{O}_{2}$ concentrations and water temperatures increase, additional physiological as well as biochemical mechanisms may be needed to keep peroxide tissue levels below a toxic threshold.

As a first and immediate reaction to environmental peroxide, a decreased swimming activity of incubated specimens was observed in the laboratory. The worms reduced their movements to a minimum, and curled up to diminish body surface contact with the water. Concomitantly oxygen uptake, which Nereis diversicolor performs through the parapods, is significantly reduced. It seems that thereby the animals try to minimize an uptake of toxic environmental peroxide.

Neither of the metabolic end-products formed during anaerobiosis, succinate and lactate, accumulated during oxic peroxide incubation. This indicates that $\sim 60 \%$ oxygen uptake was still sufficient to maintain an aerobic metabolism. Moreover it showed that environmental peroxide of up to $5 \mu \mathrm{M}$ could be readily detoxified under oxic conditions, or at least did not affect the mitochondrial respiration.

This led us to ask whether under anoxic conditions peroxide could possibly provide an alternative oxygen source, via the catalase reaction: $2 \mathrm{H}_{2} \mathrm{O}_{2} \rightarrow \mathrm{O}_{2}+2 \mathrm{H}_{2} \mathrm{O}$. The anoxic $5 \mu \mathrm{M}$ peroxide incubations clearly showed that this was not the case, as succinate as well as lactate accumulation increased under anoxic conditions with peroxide, compared to anoxic incubations without peroxide. Under anoxic conditions peroxide seems to be either a direct or an indirect stimulator of anaerobic glycolysis, deduced from the extremely high lactate levels of $60 \mu \mathrm{mol} \mathrm{g}{ }^{-1}$ dry mass, accumulated during $6 \mathrm{~h}$ anoxic peroxide incubation. Under environmental anaerobiosis Schöttler (1979) found these concentrations only after $60 \mathrm{~h}$.

Nereis diversicolor was shown to be tolerant to anaerobiosis for about $4 \mathrm{~d}$ by Schöttler (1979), who during 72 h of anoxia measured only a slight decrease in the total adenylate pool. The author attributed the predominant formation of lactate during anaerobiosis to the extraordinary mobility of $N$. diversicolor. In contrast, we found lactate formation to occur during relative immobility. Excess formation of lactate upon addition of peroxide to an anoxic incubation showed that the animals needed surplus energy to detoxify $\mathrm{H}_{2} \mathrm{O}_{2}$. and moreover indicated that lactate formation may be a general indicator of stress.

Why does Nereis diversicolor respond differently to peroxide under oxic than under anoxic environmental conditions? What is the mechanism for $\mathrm{H}_{2} \mathrm{O}_{2}$ detoxification under aerobic conditions, not being available when oxygen is depleted in the environment? When incubated with peroxide under aerobic conditions during the spawning period in April, the dorsal blood vessel of the worms turns green. This is due to oxidative decomposition of hemoglobin to biliverdin by the enzyme hemeoxygenase as indicated in Fig. 4. Under anoxic conditions the biochemical decomposition of heme is inhibited, as it requires 3 moles of oxygen per mole heme. Biliverdin formation in $N$. diversicolor naturally occurs during spring spawning periods, when freshly collected specimens exhibit green blood vessels. 


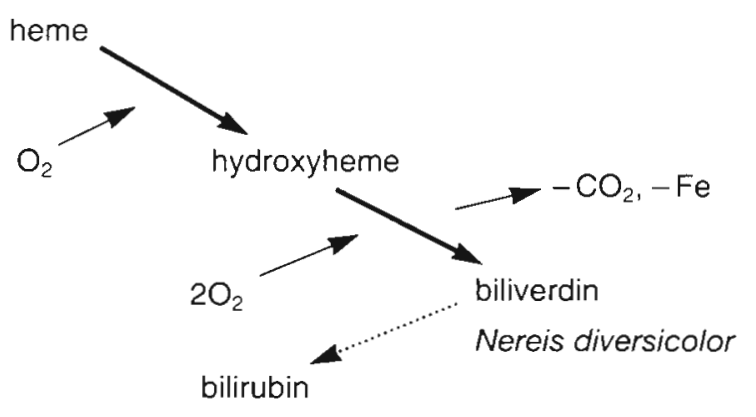

Fig. 4. Scheme of the hemeoxygenase catalysed conversion of heme to biliverdin as postulated for epitokous Nereis diversicolor. Further conversion to bilirubin is found in some vertebrates

Bilirubin, the reduction product of biliverdin, has proved to be a potent antioxidant in humans (Stocker et al. 1987, Elstner 1992). Biliverdin functions as an antioxidant in species, that do not reduce biliverdin to bilirubin (birds, amphibians, reptiles), and has been shown to prevent lipid peroxidation even more efficiently than bilirubin (Stocker et al. 1987). The significant increase of biliverdin tissue concentration during oxic peroxide incubation in April 1993 may be indicative for biliverdin functioning as antioxidant in epitokous Nereis diversicolor. Taking into account that the only other antioxidant we found was the vitamin A precursor $\beta$-carotene, an antioxidant function of biliverdin during spring seems highly probable.

In contrast, tissue of atokous worms (September 1993) contain much less biliverdin and incubation with peroxide does not stimulate biliverdin formation. This antioxidant pathway seems to be restricted to epitokous individuals. Indeed, during spawning Nereis diversicolor turns into an active swimmer and builds up a denser parapodial capillary system. Simultaneously the worms show an increasing oxygen uptake (Schöttler 1989), owing to the energy costs of active swimming. Elevated oxygen uptake may simultaneously implicate elevated oxygen radical stress.

The enzyme SOD converts internally generated $\mathrm{O}_{2}{ }^{--}$ radicals to $\mathrm{H}_{2} \mathrm{O}_{2}$ inside cells or organelles. SOD activity in Nereis diversicolor was not inducible during oxic peroxide incubation, and instead seemed to be controlled by other environmental factors with similar seasonal patterns like $\mathrm{H}_{2} \mathrm{O}_{2}$, i.e. water temperature, availability of oxygen in the sediment surface, or hydrogen sulfide content of the sediment. Anoxia per se had no clear-cut effect on SOD activities. Environmental sulfide significantly increased SOD activities in atokous animals, while the effect was less pronounced in epitokous specimens. Formation of oxygen radicals, i.e. induction of SOD activity during sulfide exposure, has been found to occur in other marine invertebrates
(Tapley \& Shick 1991). A major source of $\mathrm{O}_{2}{ }^{*}$ and $\mathrm{H}_{2} \mathrm{O}_{2}$ in mitochondria is the oxidation of reduced respiratory chain components, mainly ubichinone, which accumulate when cytochrome c-oxidase is inhibited by $\mathrm{H}_{2} \mathrm{~S}$. Anaerobically accumulated succinate functions as electron donator in the reaction (Elstner 1990). Xanthine dehydrogenase $(\mathrm{XDH})$ is converted to xanthine oxidase (XOD) during anaerobiosis, and, when the tissue is returned to normoxic conditions, produces oxygen radicals and urate. Dykens \& Shick (1988) found that tolerance towards anoxic followed by normoxic incubation of clams was partly due to a low XDH tissue content. Khan et al. (1990) postulated that the inhibition of cytochrome c-oxidase and of catalase by environmental sulfide in isolated mitochondria in vitro enhances the liberation of generated oxygen radicals and $\mathrm{H}_{2} \mathrm{O}_{2}$.

In vertebrate erythrocytes reduced oxygen availability enhances autoxidation of hemoglobin, giving rise to elevated levels of superoxide radicals (Rifkind et al. 1988). These radicals are metabolized to $\mathrm{H}_{2} \mathrm{O}_{2}$ by SOD. The resulting peroxide supposedly binds to other hemoglobin molecules (Oliver \& Brittain 1983). Possibly hematin catalysed sulfide oxidation, assumed for Nereis diversicolor by Vismann (1993), could result in a similar radical production, although experimental evidence is lacking.

With regard to the intertidal benthic fauna, it can be concluded that intracellular oxygen radical formation is enhanced by frequent changes of the environmental redox conditions and temporal fluctuations of oxygen, hydrogen peroxide and sulfide concentrations in combination with small-scale spatial inhomogenity of the redox conditions, characteristic of intertidal environments. In the case of Nereis diversicolor, increasing SOD activities upon sulfide contact plus sulfide insensitive catalase are indicative for an anoxia and sulfide induced $\mathrm{O}_{2}{ }^{-}$- formation in the worms' tissues. This suggests that this abundantly occurring species is well adapted to the highly variable environmental conditions prevailing in its habitat. Environmental peroxide poses the major threat during spring spawning time, because the worms have temporarily increased energy and oxygen demands and therefore take in higher amounts of externally formed peroxide. Besides the $\mathrm{H}_{2} \mathrm{O}_{2}$-scavenging enzyme catalase, the heme oxidation product biliverdin seems to be the major antioxidant in epitokous $N$. diversicolor specimens under oxic conditions. Epitokous worms are active swimmers, thus avoiding anoxic peroxide conditions which may prevail in the sediment, the worms' usual habitat.

Atokous worms live in the sediment, and have a lower oxygen demand. They are tolerant towards sulfide and also towards peroxide under oxic conditions. 
Under anoxic conditions with peroxide anaerobic glycolysis is increased. Lactate and succinate accumulate, and oxygen radicals are generated in the worms tissues and turned into internal $\mathrm{H}_{2} \mathrm{O}_{2}$ by the enzyme SOD. Increased internal and environmental $\mathrm{H}_{2} \mathrm{O}_{2}$ concentrations are detoxified by the enzyme catalase, which exhibits elevated activity levels in atokous Nereis diversicolor during summer and autumn.

Hydrogen peroxide acts as an environmental factor, which has an impact on the physiological reactions at lower levels (>500 $\mathrm{nM}$ ) and on the biochemistry of Nereis diversicolor at higher levels $(>3 \mu \mathrm{M})$. Peroxide toxicity is increased under environmental anoxia, a situation which the worms avoid by irrigating their burrows with oxygenated water during high tides and ebb ventilation during low tides.

Acknowledgements. We acknowledge the skillful technical assistance of Petra Wencke. Dr U. Hoeger provided the method of the biliverdin assay. We greatly appreciated the comments of 3 anonymous reviewers. This study was funded by a research grant to D.A.-O. (Ab 64/1-2) of the Deutsche Forschungsgemeinschaft.

\section{LITERATURE CITED}

Aebi, H. E. (1985). Catalase. In: Bergmeyer, H. U. (ed.) Methods of enzymatic analysis, Vol. VIII. Verlag Chemie, Weinheim, p. 273-286

Beutler, H.-O. (1985). Succinate. In: Bergmeyer, H. U. (ed.) Methods of enzymatic analysis, Vol. VII. Verlag Chemie, Weinheim, p. 25-33

Bittersohl, G. (1971). Beitrag zum toxischen Wirkmechanismus von Schwefelwasserstoff. Z. ges. Hyg. Grenzgeb. 17: 305-308

Burton, G. W., Ingold, K. U. (1984). $\beta$-Carotene: an unusual type of lipid antioxidant. Science 224: 569-573

Dykens, J. A., Shick, J. M. (1988). Relevance of purine catabolism to hypoxia and recovery in euryoxic and stenoxic marine invertebrates, particularly bivalve molluscs. Comp. Biochem. Physiol. 91C: 35-41

Elstner, F. E. (1990). Der Sauerstoff. Wissenschaftsverlag, Mannheim

Jahn, A., Oeschger, R., Theede, H. (1992). Effects of hydrogen sulfide on the metabolism of selected polychaetes from the North Sea and the Baltic. Verh. dt. zool. Ges. 85(1): 22 (in German)

Khan, A. A., Schuler, M. M., Prior, M. G., Yong, S., Coppock, R. W., Florence, L. Z., Lillie, L. E. (1990). Effects of hydrogen sulfide exposure on lung mitochondrial respiratory chain enzymes in rats. Toxicol. appl. Pharmacol. 103: $482-490$

Lindroth, A. (1941). Atmungsventilation der Polychaeten. Z. vgl. Physiol. 28: 485-532

Livingstone, D. R., de Zwaan, A., Leopold, M., Marteijn, E. (1983). Studies on the phylogenetic distribution of pyruvate oxidoreductase. Biochem. Syst. Ecol. 11: 415-425

Livingstone, D. R., Lips, F., Martinez, P. G., Pipe, R. K. (1992). Antioxidant enzymes in the digestive gland of the common mussel Mytilus edulis. Mar. Biol. 112: $265-276$
Livingstone, D. R., Stickle, W. B., Kapper, M. A., Wang, S., Zurburg, W. (1990). Further studies on the phylogenetic distribution of pyruvate oxidoreductase activities. Comp. Biochem. Physiol. 97B: 661-666

Makos, B. K., Youson, H. J. (1988). Tissue levels of bilirubin and biliverdin in the sea lamprey, Petromyzon marinus L., before and after biliary artesia. Comp. Biochem. Physiol. 91A: 701-710

Marklund, S., MarkJund, G. (1974). Involvement of the superoxide anion radical in the autoxidation of pyrogallol and a convenient assay for superoxide dismutase. Eur. J. Biochem. 47: 469-479

Moffett, J. W., Zafiriou, O. C. (1990). An investigation of hydrogen peroxide chemistry in surface waters of Vineyard Sound with $\mathrm{H}_{2}{ }^{18} \mathrm{O}_{2}$ and ${ }^{18} \mathrm{O}_{2}$. Limnol. Oceanogr. 35: $1221-1229$

Morrill, A. C., Powell, E. N., Bidigare, R. R., Shick, J. M. (1988). Adaptations of life in the sulfide system: a comparison of oxygen detoxifying enzymes in thiobiotic and oxybiotic meiofauna (and freshwater planarians). J. comp. Physiol. B 158: 335-344

Noll, F. (1974). Lactate. In: Bergmeyer, H. U. (ed.) Methoden der enzymatischen Analyse, Vol. 2. Verlag Chemie, Weinheim, p. 1521-1525

Oeschger, R., Peper, H., Graf, G., Theede, H. (1992). Metabolic responses of Halicryptus spinulosus (Priapulida) to reduced oxygen levels and anoxia. J. exp. mar. Biol. Ecol. 162: $229-241$

Oliver, J., Brittain, T (1983). A comparison between the ease of haemoglobin oxidation and modification by sulphide. Comp. Biochem. Physiol. 76B: 579-583

Palenik, B., Morel, F. M. M. (1988). Dark production of $\mathrm{H}_{2} \mathrm{O}_{2}$ in the Saragasso Sea. Limnol. Oceanogr. 33: 1606-1611

Pamatmat, M. M. (1990). Catalase activity: a variable affecting $\mathrm{H}_{2} \mathrm{O}_{2}$ distribution in Kiel Bight. Meeresforsch. 32: 261-275

Price, D., Worsfold, P. J., Mantoura, R. F . C. (1992). Hydrogen peroxide in the marine environment: cycling and methods of analysis. Trends analyt. Chem. 11: 379-384

Rifkind, J. M., Zhang, L., Heim, J. M., Levy, A. (1988). The role of hemoglobin in generating oxyradicals. In: Simic, M. G., Taylor, K. A., Ward, J. F., von Sonntag, C. (eds.) Oxygen radicals in biology and medicine. Plenum Press, New York, p. 157-162

Riisgård, H. U. (1991). Suspension feeding in the polychaete Nereis diversicolor. Mar. Ecol. Progr. Ser. 70: 29-37

Schöttler, U. (1979). On the anaerobic metabolism of three species of Nereis (Annelida). Mar. Ecol. Prog. Ser. 1: 249-254

Schöttler, U. (1989). Changes in the intermediary metabolism after transition from atokous to the epitokous stage. Investigations on Nereis virens. Verh. dt. zool. Ges. 82: 306-307 (in German)

Stocker, R., Yamamoto, Y., McDonagh, A. F., Glazer, A. N., Mames, B. N. (1987). Bilirubin is an antioxidant of possible physiological importance. Science 235: 1043-1046

Szymczak, R., Waite, T. D. (1988). Generation and decay of hydrogen peroxide in estuarine waters. Aust. J. Freshwat. Res. 39: 289-299

Tapley, D. W., Shick, J. M. (1991). Antioxidant enzyme activities in the protobranch bivalves Solemya velum and Yoldia limatula. Am. Zool. 31:671 A

Vismann, B. (1993). Hematin and sulfide removal in hemolymph of the hemoglobin-containing bivalve Scapharca inaequivalvis. Mar. Ecol. Prog. Ser. 98: 115-122

Zamora, R., Hidalgo, F. J., Tappel, A. L. (1991). Comparative 
antioxidant effectiveness of dietary $\beta$-carotene, vitamin $E$, selenium and coenzyme $Q_{10}$ in rat erythrocytes and plasma. J. Nutr. 121: 50-56

Zika, R. G., Moffett, J. W., Petasne, R. G., Cooper, W. J., Saltzman, E. S. (1985). Spatial and temporal variations of

This article was submitted to the editor hydrogen peroxide in Gulf of Mexico Waters. Geochim cosmochim. Acta 49: 1173-1184

Zika, R. G., Saltzman, E. S, Cooper, W. J (1984). Hydrogen peroxide concentrations in the Peru upwelling area. Mar Chem. 17: 265-275

Manuscript first received: October 18, 1993 Revised version accepted: January 12, 1994 